Nr 3(66), 2020, s. 233-244

https://doi.org/10.12797/Politeja.17.2020.66.16

\author{
Małgorzata FIJAE (D) \\ Uniwersytet Jagielloński \\ fijalmalgorzata@gmail.com
}

\title{
OD POPULIZMU REGIONALISTYCZNEGO DO NACJONALISTYCZNEGO
}

\author{
REFLEKSJA NAD WŁOSKIM POPULIZMEM \\ NA PRZYKŁADZIE LIGI (PÓŁNOCNEJ)
}

ABSTRACT From Regionalistic to Nationalistic Populism. Reflection on Italian Populism on the Example of the (Northern) League

The (Northern) League has been playing a key role on the Italian political scene for almost three decades. The article approaches the issue of the elements of rhetoric of the populist narrative proclaimed by the party with particular emphasis on the two types of populism: regionalistic and nationalistic populism. The purpose of the article is above all an attempt to reconstruct the most important populist characteristics and activities contributing to the League's significant electoral success and verification of the research hypothesis that the phenomenon of populism in Italy is associated with the long-standing regional character of the Italian state and the resulting attitude of putting their (often regional) interests above those of others.

Keywords: Northern League, regionalistic populism, nationalistic populism, Italian populism, Umberto Bossi, Matteo Salvini

Słowa kluczowe: Liga Północna, populizm regionalistyczny, populizm nacjonalistyczny, włoski populizm, Umberto Bossi, Matteo Salvini 
W ostatnich dekadach, począwszy od lat 80. XX w., w Europie powstało wiele partii i ruchów protestu, posługujących się w działalności politycznej metodami i hasłami o charakterze populistycznym. Sukcesy wyborcze partii zaliczanych do „nowego populizmu" w latach 90. wywołały dyskusje, na ile mogą one stanowić zagrożenie dla współczesnych demokracji zachodnioeuropejskich. Wzrost zainteresowania problematyką populizmu doprowadził jednak do terminologicznej zawiłości w tym obszarze. Populizm, będący zjawiskiem o długiej historii, nie jest prosty do zdefiniowania ${ }^{1}$. Zdaniem politologa Casa Mudde’a to ideologia opierająca się na podziale społeczeństwa na dwie homogeniczne i antagonistyczne grupy: nieskażony lud (the pure people) i skorumpowane elity (the corrupt elite), co w szerszej perspektywie objawia się tradycyjnym podziałem my-oni. Holenderski uczony położył również nacisk na fakt, że praktyka polityczna powinna służyć realizacji volonté générale ludu. Istotnym ogniwem populizmu jest także obecność charyzmatycznego przywódcy utożsamiającego się ze swoim ludem oraz proponującego proste metody rozwiązania złożonych problemów ${ }^{2}$. Warto jednak podkreślić, iż dostępne badania wskazują, że z biegiem lat, wraz z przeobrażeniami społeczno-kulturowymi i polityczno-gospodarczymi zarówno w skali globalnej, jak i regionalnej, zjawisko populizmu dezaktualizuje się, a badacze nieustannie dążą do przedstawienia jego najlepszej i najbardziej aktualnej definicji.

We Włoszech współczesna wersja populizmu, proponowana przez Ligę Północną (Lega Nord, LN)3 , spowodowała redefinicję takich pojęć, jak jednostka, społeczeństwo, naród czy państwo, a także reinterpretację relacji między tymi podmiotami. Populistyczny program partii, głoszony początkowo w formacie regionalnym, w drugiej dekadzie XXI w. stał się punktem odniesienia dla szerzenia ideologii na skalę narodową. Niniejszy artykuł poświęcony jest analizie dwóch typów populizmu: regionalistycznego (manifestowanego przez założyciela partii Umberto Bossiego) oraz nacjonalistycznego (głoszonego przez obecnego jej sekretarza Matteo Salviniego). Głównymi celami tekstu są przede wszystkim wskazanie elementów retoryki populistycznej narracji głoszonej przez Ligę i ogólna charakterystyka jej liderów oraz weryfikacja hipotezy badawczej zakładającej, że fenomen populizmu we Włoszech związany jest z mającym długą tradycję regionalnym charakterem państwa włoskiego i wynikającą z tego postawą stawiania własnych (często regionalnych) interesów ponad interesy innych krajów czy imigrantów.

Jak słusznie zauważyła polska politolożka i italianistka Joanna Sondel-Cedarmas, należy dokonać rozróżnienia pomiędzy populizmem historycznym (narodzonym w carskiej Rosji w połowie XVIII w. wraz z powstaniem ruchu Narodnictwa, ros. Народничество) а populizmem postdwudziestowiecznym (charakteryzującym się m.in. istnieniem szerokiego spektrum partii i ruchów protestu), który w literaturze przedmiotu nazywany jest neopopulizmem, populizmem trzeciej generacji bądź populizmem 2.0. Zob. Intervista a Joanna Sondel-Cedarmas, „Il Pesniero Storico. Rivista internazionale di storia delle idee" 2019, nr 5, s. 25-30. Por. Populizm w Europie. Defekt i przejaw demokracji?, red. J.-M. De Vaele, A. Pacześniak, Warszawa 2010.

2 C. Mudde, Populist Radical Right Parties in Europe, Cambridge 2007; C. Mudde, C. Rovira Kaltwasser, Populism. A Very Short Introduction, Oxford 2017.

3 Liga Północna na rzecz niepodległości Padanii, w skrócie Liga Północna (Lega Nord, LN), od wyborów parlamentarnych w 2018 r. używa nazwy Liga (Lega). 
W tym celu podjęta została próba zbadania następujących problemów: przyczyny, które zdecydowały o powstaniu partii oraz zdeterminowały jej późniejsze sukcesy polityczne, prezentowany przez nią rodzaj apelu programowego i ideologicznego, charakter i formy działalności politycznej, uzyskiwane poparcie wyborcze oraz wpływ na kształtowanie polityki Włoch. W związku z tym za konieczne uznano również odniesienie się do rezultatów wyborów parlamentarnych we Włoszech w 2018 r., a w konsekwencji próbę zbadania bezprecedensowej relacji Ligi z innym populistycznym, antysystemowym włoskim ugrupowaniem - Ruchem 5 Gwiazd (MoVimento 5 Stelle, M5S); wyniki tych wyborów to rezultat procesów o znacznie dłuższym trwaniu niż populistyczna retoryka kampanii wyborczej. W artykule przyjęto ponadto subhipotezę, że skutki populistycznej polityki Rzymu mogą doprowadzić do zagrożenia włoskiej demokracji. Przyjmując za włoską politolożką Donatellą Della Porta, że porównywanie jest podstawą każdej wie$d z y$, obraną w artykule porównawczą metodę badawczą oparto na zestawieniu wspomnianych rodzajów populizmu w celu ustalenia ich genezy i tożsamości oraz poznania ich elementów wspólnych bądź podobnych, a także istniejących między nimi zależnoścí ${ }^{4}$. Jej podstawę stanowi jakościowa analiza wybranej literatury przedmiotu z odwołaniem do programów wyborczych oraz założeń ideowych partii.

\section{POPULIZM REGIONALISTYCZNY LIGI PÓŁNOCNEJ}

Przestrzeń dla mobilizacji populistycznej we Włoszech została otwarta przez założoną w 1992 r. formację regionalną o nazwie Liga Północna. Powstała ona z inicjatywy Umberto Bossiego z połączenia stron sojuszu, zawartego w 1989 r. pomiędzy Ligą Lombardzką a kilkoma mniejszymi Ligami działającymi na północy Włoch ${ }^{5}$. Partia początkowo postrzegana była jako główny orędownik tzw. questione settentrionale, czyli zaangażowania w reprezentowanie interesów północnych regionów Włoch. Nowo powstała formacja, zobowiązując się do obrony regionalnej kultury i tradycji, ujawniła decentralizację władzy politycznej na rzecz samorządu lokalnego. Aby uzyskać widoczność, uznanie i skuteczność na szeroką skalę, pojawiała się we wszystkich wyborach lokalnych, krajowych i europejskich, choć w pierwszych latach osiągała bardzo rozczarowujące wyniki.

Pierwsza fala ekspansji wyborczej LN nastąpiła w 1992 r., kiedy osiągnęła ona drugi wynik na północy Włoch, otrzymując 17,3\% głosów. Warto nadmienić, że partia

D. Della Porta, Comparative Politics and Social Movements, [w:] Methods of Social Movements Research, red. B. Klandermans, S. Staggenborg, Minneapolis 2002, s. 286.

Liga Północna nie była ruchem zakorzenionym w kontekście terytorialnym, pokrywającym się z jednym z włoskich regionów. Założona 4 XII 1989 r., powstała z połączenia sześciu ruchów autonomicznych: Ligi Lombardzkiej, Ligi Weneckiej, Autonomicznego Piemontu, Unii Liguryjskiej, Ligi Emiliańsko-Romańskiej, Sojuszu Toskańskiego. Zob. I. Diamanti, Il male del Nord. Lega, localismo, secessione, Roma 1996, s. 85, Interventi, 33. Co więcej, w obowiązującym od 2015 r. statucie partii Liga przedstawia się jako konfederację 13 sekcji regionalnych zwanych Narodami. Zob. Statuto della Lega Nord (statut Ligi Północnej z 2015 r.), [online] http://www.leganord.org/index.php/component/ phocadownload/category/3, 10 XI 2019. 
odegrała wówczas zasadniczą rolę w inicjacji „cyklu antypolitycznego” (wł. ciclo dell’antipolitica), który w konsekwencji spowodował kryzys tzw. Pierwszej Republiki i rozwiązanie tradycyjnego włoskiego systemu partyjnego w latach 1992-19946. Spośród czynników, które doprowadziły do sukcesu wyborczego Ligi, na pierwszy plan wysuwa się fakt, że partii udało się osiągnąć popularność dzięki przekształceniu protestu regionalistycznego w ogólną walkę przeciwko systemowi rzymskiej partiokracji. Jak słusznie zauważył włoski politolog i socjolog Roberto Biorcio, autor książki badającej fenomen włoskiego populizmu od kryzysu Pierwszej Republiki na początku lat 90. XX w. do czasów rządu Matteo Renziego, partia Bossiego przekształciła regionalizm w formę regionalistycznego populizmu (wł. populismo regionalista) ${ }^{7}$. Cel w postaci osiągnięcia autonomii przez północne regiony Włoch miał w radykalny sposób zlikwidować potęgę tradycyjnych partii i biurokracji państwowej ${ }^{8}$. Jak dowiódł Biorcio, regionalna tożsamość stała się punktem odniesienia serii napięć i konfliktów silnie odczuwanych wśród społeczeństwa: napięć pomiędzy obywatelami a klasą polityczną, pomiędzy rdzennymi mieszkańcami Północy a imigrantami (najpierw pochodzącymi z południa Włoch, następnie spoza UE), pomiędzy zwykłymi ludźmi a różnymi formami przestępczości i dewiacji?.

Za główne powody sukcesu LN należy uznać oryginalną reinterpretację regionalizmu w kluczu populistycznym oraz połączenie powszechnego protestu z problemami tożsamościowymi. Odnosząc się do ludności zamieszkującej północ Włoch, partia Bossiego wprowadziła dwa modele rozumienia narodu: 1) w kategorii demosu (to znaczy narodu, ludu jako całości, a jednocześnie jako zwykłych ludzi, plebsu, popularnych mas przeciwko elitom) oraz 2) w kategorii etnosu (to znaczy ludzi jako grup etnicznych). W ten sposób Liga stopniowo kształtowała swoją tożsamość polityczną, odnoszącą się do idei „ludu” zdefiniowanego w kategoriach etnokulturowych i terytorialnych, wykształcając dychotomię my-oni. Oni rozumiani w kategorii wroga, potęgi państwa centralnego ze stolicą w Rzymie, tradycyjnych partii politycznych, Włochów pochodzących z Południa czy imigrantów spoza UE ${ }^{10}$.

Strategia Bossiego została wykorzystana do uzyskania autonomicznej władzy, której domagano się początkowo w kontekście federalnej reformy państwa, a następnie możliwości secesji Włoch Północnych od pozostałej części kraju przy pomocy inwazji

6 C. Marletti, Il ciclo dell'antipolitica e i risultati delle elezioni del 13 giugno in Italia. Verso un nuovo clima d'opinione?, „Comunicazione Politica” 2002, nr 1, s. 9-30. Alfio Mastropaolo definiuje antypolitykę jako apel przeciwko systemowi skonsolidowanej władzy politycznej w imieniu ludu: antypolityka nie jest niczym innym niż uaktualniona wersja odwiecznego fenomenu, jakim jest populizm. A. Mastropaolo, Antipolitica: all'origine della crisi italiana. L'ancora del mediterraneo, Napoli 2000, s. 24, Gomene, 12.

R. Biorcio, La Lega Lombarda come attore politico: dal federalismo al populismo regionalista, [w:] La Lega Lombarda, red. R. Mannheimer, Milano 1991, s. 34-82, Idea; R. Biorcio, Il populismo nella politica italiana. Da Bossi a Berlusconi, da Grillo a Renzi, Milano 2015, Passato Prossimo, Presente Italiano.

8 Zob. D. McDonnel, A Weekend in Padania: Regionalist Populism and the Lega Nord, „Politics” 2006, Vol. 26, nr 2, s. 126-132.

9 R. Biorcio, I populismi in Italia, „Rivista delle Politiche Sociali” 2012, nr 1, s. 3-4. 
nowego narodu: Padanii. Na lata 1996-1997 przypadła intensywna kampania tworzenia pótnocnowtoskiego państwa, ukonstytuowanego wokół kluczowych wartości kulturowych, takich jak język, tradycja, zwyczaje i religia, ale także wspólnej pamięci historycznej, obejmującej oprócz wydarzeń historycznych również mity i legendy dotyczące przeszłości tej wspólnoty. Koncentrując inicjatywę polityczną na doprowadzeniu do secesji Padanii od pozostałej części Włoch oraz na budowaniu nowego narodu, Liga przywołała klasyczny schemat tradycji wynalezionej, z odniesieniami do wspólnego pochodzenia i historii mieszkańców północnych Włoch ${ }^{11}$.

W regionalistycznej wersji populizmu, charakteryzującej się zestawieniem ludności regionów północnych Włoch z państwem centralnym, można odnaleźć zarówno peryferyjność polityczną regionów lepiej rozwiniętych gospodarczo, jak i napięcia pomiędzy zdecydowaną większością obywateli a rządzącymi partiami politycznymi. Faktem jest, że Liga znacznie skuteczniej niż konkurencyjne wówczas partie zdołała przełożyć niezadowolenie i protest obywateli na poparcie wyborcze, łącząc walkę z polityką partyjną w celu obrony konkretnych (regionalnych) interesów. Należy zwrócić uwagę na zdolność Bossiego do nawiązywania relacji oraz identyfikowania się ze sposobem myślenia warstw społecznych Północy. Jak zaznaczył założyciel partii: Może będzie to naiwnym, uproszczonym przekonaniem, ale czuje, że tam, gdzie sa ludzie, jest dobro. Zto czai się w patacach wtadzy lub w mafijnych koputach ${ }^{12}$. Analogicznie główny ideolog partii, zmarły w 2001 r. federalista Gianfranco Miglio, podkreślając umiejętność skutecznego odgrywania roli populistycznego przywódcy przez Bossiego, stwierdzil, że pierwsza i podstawowa cechą lidera Ligi Pótnocnej jest umiejętność dostrzegania i utożsamiania sie z problemami i aspiracjami mieszkańców pótnocnej części Wtoch ${ }^{13}$.

Sposób, w jaki partia i jej przywódca zaproponowała i połączyła etnonacjonalizm z populizmem należy uznać za oryginalny i skuteczny. Pomysł założenia ruchu na rzecz obrony interesów własnego regionu Bossi wiązał z waloryzacją profilu etnicznego ludności. Lidze udało się pozyskać uwagę i posłuch ogółu również dzięki kontrowersyjnym czy często przekraczającym normy społeczne zachowaniom oraz wykorzystaniu dialektu w debacie publicznej. Analizując ówczesną strategię komunikacyjną LN, można odnieść wrażenie, że opierała się ona na szeregu postaw i stanowisk odwołujących się w swojej retoryce do idei i woli ludu, pochodzącego z najniższego szczebla stratyfikacji społecznej. Sposób mówienia oraz ubierania się Bossiego stały się niejako gwarancją autentyczności oraz docenienia i waloryzacji ludowego stylu życia. Co więcej, kulturowym modelem odniesienia były pracowitość, uczciwość i zaradność - zalety zwykłych ludzi, przeciwstawiane technicznemu zarządzaniu organów państwa centralnego. Odwołując się do kontekstu terytorialnego, Liga wytworzyła relacje pomiędzy partią a ludnością i została uznana za ugrupowanie stojące po stronie lokalnej ludności, zaangażowanej w obronę jej terytorium, bezpieczeństwa i interesów. Cieszyła się poparciem wyborczym dzięki wytworzonej przez siebie regionalnej tożsamości.

11 Zob. The Invention of Tradition, red. E.J. Hobsbawm, T.O. Ranger, Cambridge 1983.

12 U. Bossi, D. Vimercati, Vento del Nord, Segrate 1992, s. 187.

13 Cyt. za: R. Biorcio, Il populismo nella politica italiana..., s. 49. 
Sukcesy wyborcze LN pozwoliły jej stać się jednym z najważniejszych protagonistów włoskiego życia politycznego i przez wiele lat uczestniczyć w centroprawicowych rządach kierowanych przez Silvio Berlsuconiego. Uwikłanie się Bossiego w skandale korupcyjne na początku drugiej dekady XXI w. wywołało poważny kryzys w partii, gwałtowny spadek poparcia wyborczego, odejście działaczy partyjnych i rezygnację lidera z przewodzenia partią. Nowym sekretarzem partii został wówczas Roberto Maroni, który zajmowal to stanowisko do 7 grudnia $2013 \mathrm{r}$.

\section{POPULIZM NACJONALISTYCZNY LIGI MATTEO SALVINIEGO}

Nowa faza ożywienia LN rozpoczęła się wraz z objęciem przez Salviniego w grudniu 2013 r. stanowiska sekretarza federalnego partii. Przejęcie przezeń przywództwa zostało przez politologów dostrzeżone i uznane za istotną cezurę. Nowy lider, zmieniając diametralnie profil Ligi, jej strategię i pozycję polityczną, doprowadził do wzrostu poparcia wyborczego partii. Przy jednoczesnym poszerzaniu horyzontów terytorialnych - z północnowłoskich na ogólnowłoskie - przesunął swój punkt odniesienia w prawo, o czym piszą szczegółowo w książce La Lega di Salvini. Estrema destra di governo włoscy naukowcy, politolog Gianluca Passarelli oraz socjolog Dario Tuorto ${ }^{14}$. Już kilka dni po swojej elekcji na nadzwyczajnym kongresie partii w Turynie Salvini ogłosił, że na poziomie międzynarodowym priorytetem jest zniszczenie euro oraz odbudowanie Europy, dodając: mówię więc tak jedynie sojuszom, które nie są za jej europeizacją: Francuzom Le Pen, Holendrom Wildersa, Austriakom Mölzera, Finlandczykom... w sumie wszystkim tym, którzy popierają idee Europy Ojczyzn ${ }^{15}$.

Potraktowanie jako politycznego punktu odniesienia Frontu Narodowego/Zjednoczenia Narodowego Marine Le Pen stanowi jeden z dwóch podstawowych filarów nowej strategii politycznej Salviniego ${ }^{16}$. Druga zmiana odzwierciedla natomiast ogólną tendencję lidera Ligi do (auto)personalizowania polityki i pośredniczenia w niej za pomocą mediów społecznościowych. Nowy przywódca w celu bezpośredniego kontaktu z wyborcami kładzie duży nacisk na swoją obecność w programach telewizyjnych, ożywiając tym samym tzw. telepopulizm, stworzony i mocno propagowany wcześniej przez Berlusconiego. Aby zdobyć uznanie „zwykłych ludzi”, Salvini z upodobaniem kreuje się - głównie via Twitter, Instagram i Facebook - na „swojskiego chłopaka” identyfikującego się ze swoimi wyborcami, pochodzącymi przeważnie z klasy ludowej.

Zmiany wprowadzone przez nowego lidera zaczęły być silnie akcentowane od tradycyjnego wiecu partii w lombardzkiej miejscowości Pontida w 2015 r., podczas którego obecni byli przybyli z południa Włoch reprezentanci komitetów „My z Salvinim”,

14 G. Pasarelli, D. Tuorto, Lega di Salvini. Estrema destra di governo, Bologna 2018, Contemporanea. Autorzy w 2012 r. stworzyli inną monografię traktującą o Lidze Północnej i Padanii: Lega \& Padania. Storie e luoghi delle camicie verde, Bologna 2012.

15 Cyt. za: G. Caldiron, Dal verde al Nero. La Lega di Salvini sceglie Marine Le Pen, „Europa” 2013, 12 XII.

16 Dość wspomnieć obecność Marine Le Pen jako gościa honorowego na kongresie Ligi w Turynie. 
mających pomóc Lidze stać się partią ogólnonarodową. Salvini porzucił wówczas koncepcję dotychczasowo postrzeganych granic Padanii, przenosząc uwagę na południowe regiony Włoch. Liga z partii ksenofobicznej i secesjonistycznej stała się partią ksenofobiczną i rasistowską, czego przykładem może być zaprezentowany podczas zjazdu partii w Pontidzie (w dużej mierze poświęconego kwestii przyjmowania imigrantów z Afryki) nowy „symbol” partii: buldożer (wł. la ruspa), będący silną emanacją agresji w stosunku do elit politycznych, ale również imigrantów czy obozowisk Romów. Natomiast na kongresie partii w Parmie w 2017 r. Salvini zdefiniował aktualną linię swojej administracji, określając ją nadal jako federalną, aczkolwiek już nie niepodległościową i secesjonistyczną.

Innymi elementami strategii nowego lidera są szeroko rozumiany eurosceptycyzm oraz dążenie do wyjścia Włoch ze strefy euro. Sloganem „Basta Euro” partia próbowała przedstawić się jako prawdziwa i unikalna opozycja wobec utraty suwerenności oraz polityki UE. Salvini świadomie wpisuje się w nastroje włoskiej opinii publicznej, bowiem poparcie dla Ligi w dużym stopniu uzależnione było od spadku zmiany postrzegania przez Włochów spraw dotyczących UE. W 2014 r. tylko jedna trzecia z nich wyrażała zaufanie do instytucji unijnych ${ }^{17}$.

(Auto)kreacja Salviniego jako populistycznego lidera dokonywana jest nie tylko poprzez starannie przemyślane przedstawienie jego programu politycznego, lecz także przez manifestowanie jego charyzmatycznej osobowości. Włosi cenią go za komunikatywność i prostotę. W swojej autobiografii ${ }^{18}$, zredagowanej przy współpracy specjalistów z zakresu public relations, Salvini przedstawia się jako człowiek prosty, wywodzący się z ludu, przeciwny elitom, skuteczny, choć niepozbawiony wad. Na dowód własnej przeciętności zapewnia np., że na co dzień ubiera się $w$ dżinsy i koszulę, a pitkę nożna zawsze miat we krwi ${ }^{19}$. Prezentuje się jako symbol - przywódca rzucający wyzwanie dotychczasowym zaniedbaniom i bierności polityków, a zarazem jako lider wykazujący się odwagą, siłą i determinacją w rozwiązywaniu problemów życia publicznego. Jak dowiódł polski italianista i historyk Piotr Podemski, autorzy książki prezentują Salviniego jako populistyczną wersję primus inter pares, zwykłego człowieka niewywyższającego się ponad masy swych zwolenników. ${ }^{20}$ Zgodnie z deklaracjami lider Ligi to normalny cztowiek marzący o normalnym kraju, zainteresowany politykq wśród ludzi i dla ludzi $i^{21}$.

Analizując aktualny populistyczny dyskurs „narodowej” Ligi Salviniego, należy zauważyć, że przypomina on w znacznej mierze realizowany wcześniej przez partię

17 Bardzo sceptyczne jest stanowisko Włochów wobec waluty euro: $45 \%$ społeczeństwa włoskiego to zwolennicy wspólnej waluty, $40 \%$ to jej przeciwnicy. Stanowi to drugi najgorszy wynik w krajach UE co do euro jako wspólnej waluty. Zob. Flash Eurobarometer 458. The Euro Area. Report, X 2017, TNS Political \& Social, s. 8, [online] https://ec.europa.eu/commfrontoffice/publicopinion/index.cfm/ Survey/getSurveyDetail/instruments/FLASH/surveyKy/2158, 18 VI 2020.

18 M. Salvini, Secondo Matteo. Follia e coraggio per cambiare il paese, Milano 2016. Tytuł książki stanowi grę słów. Secondo Matteo może być interpretowane jako nawiązanie do Ewangelii według św. Mateusza bądź do ówczesnego premiera Włoch Matteo Renziego.

19 Tamże, s. 51, 341.

20 P. Podemski, Neoautorytaryzm po wtosku. Matteo Salvini i Liga (Pótnocna): stan wiedzy i niewiedzy, wystąpienie na konferencji pt. Demokracja, demokracja nieliberalna czy neoautorytaryzm?, Warszawa 2018.

21 Tamże, s. 114. 
program regionalny. Domaganie się niepodległości czy autonomii dla bardziej bogatych regionów w wielu przypadkach jest podobne do obecnych zachowań nacjonalistów, którzy żądają większej niezależności od UE. Podobnie jak wcześniej kładzie się nacisk na obronę przed wrogami, innymi, obcymi, chcącymi solidarności, przed różnie pojmowaną kategorią migrantów, zagrażających terytorium państwa „narodowego”. Widoczna jest więc duża konwergencja pomiędzy wcześniejszą regionalno-populistyczną polityką Ligi a jej obecnym populizmem o charakterze narodowym. W obu przypadkach partia kreuje się na obrońcę ludu przed polityką państwa centralnego oraz UE. Strategia stosowana przez Salviniego w duchu populistycznym, nacjonalistycznym i antyeuropejskim ma na celu głównie pobudzenie w społeczeństwie strachu przed imigrantami oraz wprowadzenie Włoch na odmienną od dotychczasowej ścieżkę przez obronę narodowej suwerenności przed polityką Brukseli. W tradycji włoskiej kultury politycznej nowa odsłona fundamentalnego eurosceptycyzmu Ligi klasyfikowana jest jako banalny prawicowy populizm, populistyczny bunt czy też pusty nacjonalizm ${ }^{22}$.

\section{SOJUSZ RZĄDOWY LIGI SALVINIEGO Z RUCHEM 5 GWIAZD}

W obecnej debacie na temat populizmu we Włoszech nacisk kładzie się nie tyle na tradycyjny protest polityczny, ile na niezadowolenie ze współczesnych liberalnych demokracji. Za przykład uznać można populistyczno-radykalną koalicję rządową Ligi z M5S, będącą konsekwencją wyborów parlamentarnych, które odbyły się we Włoszech 4 marca 2018 r. Dostrzegając podobieństwa w próbie wyrażania nieufności i protestów obywateli wobec klasy politycznej, Salvini próbował nawiązać sojusz z M5S już w 2016 r., wyrażając sprzeciw wobec ówczesnego rządu Renziego. Należy jednak podkreślić, że ożywiając populistyczne nastroje wśród włoskich wyborców, lider Ligi skupiał swoją działalność wokół tematów odmiennych niż te podejmowane przez Ruch. Program, styl pracy i kultura M5S mają odmienny profil aniżeli europejska prawica populistyczna. Podczas gdy proekologiczny Ruch skupia się przede wszystkim na rozwoju demokracji uczestniczącej i wszelkich formach demokracji bezpośredniej, Liga - ukazując swoje mocno prawicowe poglądy - kładzie nacisk na kwestie związane z obroną tożsamości narodowej Włochów, a także ochroną przed napływem nielegalnych imigrantów.

W świetle analizy umowy rządowej ${ }^{23}$, dokonanej przez włoski instytut badawczy $\mathrm{Qu}$ orum/YouTrend bezpośrednio po zawarciu kompromisu dwóch opozycyjnych (sic!) sił politycznych, warto podkreślić, że Liga oraz M5S, tworzące od 1 czerwca 2019 r. rząd

22 M. Brunazzo, M. Gilbert, Insurgents against Brussels: Euroscepticism and the Right-wing Populist Turn of the Lega Nord since 2013, "Journal of Modern Italian Studies” 2017, Vol. 22, nr 5, s. 626; A. Cento Bull, Lega Nord: A Case of Simulative Politics?, „South European Society and Politics” 2009, Vol. 14, nr 2, s. 130-131, https://doi.org/10.1080/13608740903037786; D. Albertazzi, A. Giovannini, A. Seddone, „No Regionalism Please, We Are Leghisti!” The Transformation of the Italian Lega Nord under the Leadership of Matteo Salvini, „Regional \& Federal Studies” 2018, Vol. 28, nr 5, s. 657-658.

23 Contratto per il governo del cambiamento, [online] https://download.repubblica.it/pdf/2018/politica/contratto_governo.pdf, 1 XI 2019. 
koalicyjny, szukając kolegialności, wyłączyły przed nawias jako czynnik wspólny szeroko pojętą wizję poglądów antyestablishmentowych $\mathrm{z}$ równoczesną afirmacją prymatu instytucji narodowych oraz krytyką prowadzonej dotychczas przez rząd polityki zagranicznej, przede wszystkim relacji Włoch z UE ${ }^{24}$. Zasadniczo fuzja dwóch oryginalnych i odmiennych programów politycznych doprowadziła do powstania umowy będącej kompromisem osiągniętym ze szkodą dla gospodarki państwa i harmonogramu realizacji różnych przedsięwzięć. W tym kontekście jasno widać rozbieżność między sposobem postrzegania spraw przez ugrupowania a rzeczywistością. Nie ulega wątpliwości, że to Liga pozostawała hegemonem w ustaleniach dotyczących bezpieczeństwa narodowego oraz sprawiedliwości. Niejasne i kontrowersyjne pozostawały jednocześnie kwestie związane $\mathrm{z}$ infrastrukturą, w których trudno było połączyć dwie odmienne wizje $\mathrm{e}^{25}$. W konsekwencji stało się to przyczyną rozpadu rządowej koalicji ${ }^{26}$. Jak wynika z analizy, to Liga zdawała się odgrywać bardziej znaczącą rolę zarówno w negocjacjach wspomnianej umowy rządowej, jak i w kierowanym przez Giuseppe Contego rządzie, co zostało ujęte w sondażach dotyczących percepcji zarówno partii, jak i jej lidera. Istotnie, po 14 miesiącach sprawowania władzy poparcie dla Salviniego wzrosło do $38 \%$, co doprowadziło do wywołania przez polityka kryzysu koalicyjnego. W konsekwencji 20 sierpnia 2019 r. premier Conte złożył dymisję na ręce prezydenta Sergio Matarelli. Kryzys, ku zaskoczeniu Salviniego, został rozwiązany dwa tygodnie później - powstał wówczas nowy rząd, składający się z M5S oraz Partii Demokratycznej (Partito Democratico, PD), któremu przewodniczy dotychczasowy premier Conte. Ipso facto oznaczało to przejście Ligi Salviniego do opozycji ${ }^{27}$.

\section{PODSUMOWANIE}

Analiza dwóch typów populizmu reprezentowanych na przestrzeni lat przez Ligę regionalistycznego oraz nacjonalistycznego - dostarcza przeglądu wielu aspektów związanych z tym terminem. Po pierwsze, odsłania różnorodność komunikatów kierowanych przez politycznych liderów do wyborców. W tym przypadku, mimo zróżnicowania populistycznego dyskursu, odmiennego w obu wersjach populizmu, cechą wspólną pozostaje deklarowana przez przywódców partii troska o lud - od ściśle związanej z etniczną definicją narodu wizji Bossiego do ogólnie rozumianej grupy obywateli,

24 Il "Contratto di Governo" di M5S e Lega ai raggi X, $25 \mathrm{~V}$ 2018, [online] https://www.youtrend.it/ 2018/05/25/il-contratto-di-governo-di-m5s-e-lega-ai-raggi-x-report-cattaneo-zanetto/, 1 XI 2019.

25 Fenomeno Salvini. Chi è, come comunica, perchè lo votano, red. G. Diamanti, L. Pregliasco, Roma 2018, s. 101-104, Nodi.

26 Dość wspomnieć, że sprzyjająca narodowemu biznesowi Liga dążyła do kontynuowania tunelu pod Alpami, który umożliwiałby szybkie połączenie kolejowe pomiędzy francuskim Lyonem a włoskim Turynem, natomiast proekologiczny M5S poddał głosowaniu w Senacie wniosek o przerwanie prac.

27 Sytuację tę należy uznać za kolejne zjawisko bez precedensu w historii Włoch, zważywszy na fakt, iż w poprzednich wyborach populiści pod przywództwem Luigiego Di Maio zwyciężyli właśnie dzięki przedstawianiu siebie w silnej opozycji do rządzących wówczas socjaldemokratów z PD, zarzucając im elitaryzm i podporządkowywanie się polityce UE. 
wszystkich Włochów. Po drugie, na populistyczny dyskurs składa się podkreślanie rangi lidera. Zarówno w przypadku Bossiego, jak i Salviniego dostrzec można znaczącą rolę płci polityków kreowanych na „ojca narodu” - wcześniej padańskiego, teraz włoskiego, doskonale łączącą ideę dbałości o los narodu z praktyką charyzmatycznego przywódcy - wcześniej regionalnego, teraz scentralizowanego. Po trzecie, polityczne emanacje populizmu w wersji Ligi w drodze po zdobycie władzy pokazują jej status w systemie partyjnym Włoch. Należy zwrócić uwagę, że w obydwu wariantach populizmu partia osiągnęła wysoki poziom relewancji - współtworzyła gabinety rządowe.

$\mathrm{Na}$ opisywaną problematykę można patrzeć także z odmiennej perspektywy; z punktu widzenia skutków polityki populistycznej związanych z zagrożeniem dla włoskiej demokracji. Dzisiaj, po niemal 30 latach od powstania tzw. Drugiej Republiki Włoskiej, obserwujemy w tym kraju, ale i w Europie, kryzys idei demokratycznych. Za jego symbol niewątpliwie można uznać postać Salviniego i zrzeszonych z nim przeciwników zjednoczonej, demokratycznej Europy. Powodów zwrotu od demokracji ku nacjonalizmowi jest wiele, wśród nich deficyt demokratycznych procedur i obyczajów czy tabloidyzacja życia politycznego. Trudno też powiedzieć, czy to kryzys tożsamości związany z globalizacją. Na pewno połączenie populizmu z nacjonalizmem w wersji proponowanej obecnie przez Ligę wprowadza Włochy na niesprecyzowaną drogę narodową. Objawia się to różnego rodzaju resentymentami i kompleksami, prowadzącymi m.in. do ksenofobii wobec uchodźców.

W wyniku analizy tych fundamentalnych uwarunkowań należy stwierdzić, że populizm zaproponowany przez Ligę w latach $90 . \mathrm{XX}$ w. jest kontynuowany, aczkolwiek pod kierownictwem Salviniego jego wersja uległa zmianie. Zaangażowanie w politykę Bossiego początkowo miało charakter wyłącznie etnoregionalny. Przekształcając początkowy regionalizm partii w regionalistyczny populizm, Bossi co prawda wykraczał poza zwykły ruch protestacyjny przeciwko partiokracji, ale zachowywał znaczną spójność ze swoją pierwotną tożsamością. Liga Salviniego, przyjmująca za punkt odniesienia Front Narodowy/Zjednoczenie Narodowe, nie jest już ani secesjonistyczna, ani antyrzymska - zastąpiła populizm regionalistyczny populizmem nacjonalistycznym, który wyraźnie opowiada się za koncepcją Europy Ojczyzn.

\section{BIBLIOGRAFIA}

Albertazzi D., Giovannini A., Seddone A., ,No Regionalism Please, We Are Leghisti!” The Transformation of the Italian Lega Nord under the Leadership of Matteo Salvini, ,Regional \& Federal Studies" 2018, Vol. 28, nr 5, https://doi.org/10.1080/13597566.2018.1512977.

Baldini G., Populismo e democrazia rappresentativa in Europa, „Quaderni di Sociologia” 2014, nr 65, https://doi.org/10.4000/qds.365.

Bankowicz M., Wtoska tożsamość narodowa a kontekst europejski, [w:] Niemcy, Europa, Świat: studia międzynarodowe. Księga pamiątkowa poświęcona Profesorowi Erhardowi Cziomerowi, red. I. Stawowy-Kawka, Kraków 2007.

Biorcio R., Ipopulismi in Italia, „Rivista delle Politiche Sociali” 2012, nr 1. 
Biorcio R., Il populismo nella politica italiana. Da Bossi a Berlusconi, da Grillo a Renzi, Milano 2015, Passato Prossimo, Presente Italiano.

Biorcio R., La Lega Lombarda come attore politico: dal federalismo al populismo regionalista, [w:] La Lega Lombarda, red. R. Mannheimer, Milano 1991, Idea.

Biorcio R., La Padania promessa, Milano 1997, Nuovi saggi / Il saggiatore.

Biorcio R., La rivincita del Nord. La Lega dalla contestazione al governo, Roma 2010.

Bossi U., Il mio progetto. Discorsi sul federalismo e la Padania, Milano 1996.

Bossi U., Intervento al congresso della Lega Nord, Milano 1991.

Bossi U., Vento del Nord, Segrate 1992.

Brunazzo M., Gilbert M., Insurgents against Brussels: Euroscepticism and the Right-wing Populist Turn of the Lega Nord since 2013, „Journal of Modern Italian Studies”, 2017, Vol. 22, nr 5, https://doi.org/10.1080/1354571x.2017.1389524.

Caldiron G., Dal verde al. Nero. La Lega di Salvini sceglie Marine Le Pen, „Europa” 2013, 12 XII. Cento Bull A., Lega Nord: A Case of Simulative Politics?, „South European Society and Politics” 2009, Vol. 14, nr 2, https://doi.org/10.1080/13608740903037786.

Contratto per il governo del cambiamento (umowa rządowa pomiędzy Ruchem 5 Gwiazd a Ligą), [online] https://download.repubblica.it/pdf/2018/politica/contratto_governo.pdf.

Corbetta P., Gualmini E., Il partito di Grillo, Bologna 2013, Contemporanea, 221.

Della Porta D., Comparative Politics and Social Movements, [w:] Methods of Social Movements Research, red. B. Klandermans, S. Staggenborg, Minneapolis 2002.

Diamanti I., Il male del Nord. Lega, localismo, secessione, Roma 1996, Interventi, 33.

Diamanti I., La Lega. Geografia, storia e sociologia di un nuovo soggetto politico, Roma 1993, Saggi. Diani M., Linking Mobilization Frames and Political Opportunities: Insights from Regional Populism in Italy, „American Sociological Review” 1996, Vol. 61, nr 6, https://doi.org/10. $2307 / 2096308$.

Dudała R., System polityczny współczesnych Włoch. Dynamika zmian, Kielce 2019.

Fenomeno Salvini. Chiè, come comunica, perchélo votano, red. G. Diamanti, L. Pregliasco, Roma 2019, Nodi.

Il „Contratto di Governo” di MSS e Lega ai raggi X, 25 V 2018, [online] https://www.youtrend. it/2018/05/25/il-contratto-di-governo-di-m5s-e-lega-ai-raggi-x-report-cattaneo-zanetto/.

The Invention of Tradition, red. E.J. Hobsbawm, T.O. Ranger, Cambridge 1983.

Itanes, Vox populi. Il voto ad alta voce del 2018, Bologna 2018.

Lega Nord, Programma per le elezioni, Milano 2006.

Lega Nord, Programma per le elezioni politiche del 1994, Milano 1994.

Lega Nord, Programma politica, Programma Elettorale per la Padania Elezioni Politiche del 21 Aprile 1996.

Lega Salvini Premier, Programma di governo per le elezioni politiche 2018, [online] https://www. leganord.org/eventi/politiche-2018.

Lega Salvini Premier, Programma per le elzeioni europee 2019, [online] https://www.leganord. org/eventi/europee-2019.

Machelski Z., System polityczny Wtoch, Warszawa 2010.

Machelski Z., Wtochy: między autonomia lokalna, unitaryzmem, regionalizmem i federalizmem, [w:] Ustrój polityczny państwa. Polska, Europa, świat, red. S. Sulowski, J. Szymanek, Warszawa 2013. 
Marletti C., Il ciclo dell'antipolitica e i risultati delle elezioni del 13 giugno in Italia. Verso un nuovo clima d'opinione?, „Comunicazione Politica” 2002, nr 1.

Mastropaolo A., Antipolitica: all'origine della crisi italiana. L'ancora del mediterraneo, Napoli 2000, Gomene, 12.

McDonnel D., A Weekend in Padania: Regionalist Populism and the Lega Nord, „Politics” 2006, Vol. 26, nr 2, https://doi.org/10.1111/j.1467-9256.2006.00259.x.

Michalak B., Partie protestu w Europie Zachodniej. Analiza relewancji politycznej, Toruń 2008.

Mudde C., Populist Radical Right Parties in Europe, Cambridge 2007.

Mudde C., Rovira Kaltwasser C., Populism. A Very Short Introduction, Oxford 2017.

Passarelli G., Populists and the Lega Nord, [w:] The Oxford Handbook of Italian Politics, red. E. Jones, G. Pasquino, Oxford 2015, Oxford Handbooks in Politics \& International Relations.

Pasarelli G., Tuorto D., Lega di Salvini. Estrema destra di governo, Bologna 2018, Contemporanea. Pasarelli G., Tuorto D., Lega \& Padania. Storie e luoghi delle camicie verde, Bologna 2012.

Podemski P., Neoautorytaryzm po wtosku. Matteo Salvini i Liga (Pótnocna): stan wiedzy i niewiedzy, wystąpienie na konferencji pt. Demokracja, demokracja nieliberalna czy neoautorytaryzm?, Warszawa 2018.

Populizm w Europie. Defekt i przejaw demokracji?, red. J.-M. De Vaele, A. Pacześniak, Warszawa 2010.

Profil Matteo Salviniego na Facebooku, [online] https://www.facebook.com/salviniofficial/.

Profil Matteo Salviniego na Instagramie, [online] https://www.instagram.com/matteosalvini official/.

Profil Matteo Salviniego na Twitterze, [online] https://twitter.com/matteosalvinimi.

Ruzza C., Fella S., Re-inventing the Italian Right. Territorial Politics, Populism and „Post-fascism”, London 2009.

Salvini M., Secondo Matteo. Follia e coraggio per cambiare il paese, Milano 2016.

Sondel-Cedarmas J., Intervista a Joanna Sondel-Cedarmas, „Il Pesniero Storico. Rivista internazionale di storia delle idee" 2019 , nr 5.

Statuto della Lega Nord (statut Ligi Północnej z 2015 r.), [online] http://www.leganord.org/ index.php/component/phocadownload/category/3.

Taguieff P.-A., Lillusione populista. Dall'arcaico al mediatico, Milano 2003, Sintesi.

Wtochy wielokulturowe. Regionalizmy, mniejszości, migracje, red. K. Golemo, Kraków 2003, Societas - Ksiegarnia Akademicka, 72.

Mgr Małgorzata FIJAŁ - doktorantka na Wydziale Studiów Międzynarodowych i Politycznych Uniwersytetu Jagiellońskiego. Magister europeistyki UJ. Jej zainteresowania naukowe koncentrują się na polityce, kulturze i społeczeństwie współczesnych Włoch. Przygotowuje rozprawę doktorską na temat koncepcji Padanii. Stypendystka programów Komisji Europejskiej, m.in. na włoskich uniwersytetach w Perugii, Bari, Padwie i Rzymie. Współpracowała z Ambasadą RP przy Stolicy Apostolskiej oraz Wydziałem Konsularnym Ambasady RP w Rzymie. Uczestniczka międzynarodowej wymiany kulturowej w USA. 